\title{
The effect of working capital management on profitability
}

\author{
Ntui Ponsian", Kiemi Chrispina', Gwatako Tago ${ }^{1}$, Halim Mkiibi ${ }^{2}$ \\ ${ }^{1}$ Lecturer, Accountancy and Finance, St. Augustine University of Tanzania (SAUT) \\ ${ }^{2}$ Bachelor of Business Administration (BBA), St. Augustine University of Tanzania (SAUT)
}

\section{Email address:}

ponsianproti@yahoo.com (N. Ponsian), postyankar@yahoo.com (K. Chrispina), gwatakotago@yahoo.com (G. Tago), maundu69@gmail.com (H. Mkiibi)

\section{To cite this article:}

Ntui Ponsian, Kiemi Chrispina, Gwatako Tago, Halim Mkiibi. The Effect of Working Capital Management on Profitability. International Journal of Economics, Finance and Management Sciences. Vol. 2, No. 6, 2014, pp. 347-355. doi: 10.11648/j.ijefm.20140206.17

\begin{abstract}
The purpose of this study is to find out the effect of working capital management on company profitability. The study aims at examining the statistical significance between company's working capital management and profitability. In light of this objective the study adopts quantitative approaches to test a series of research hypotheses. A sample of three (3) manufacturing companies listed on the Dar es Salaam Stock Exchange (DSE) is used for a period of ten years (2002-2012) with the total of 30 observations. Data is analyzed on quantitative basis using Pearson's correlation and Regression analysis (Ordinary Least Square). The key findings from the study are; Firstly, there exists a positive relationship between cash conversion cycle and profitability of the firm. This means that as the cash conversion cycle increases it will lead to an increase in profitability of the firm, and managers can create a positive value for the shareholders by increasing the cash conversion cycle to a reasonable level; Secondly, there is a negative relationship between liquidity and profitability showing that as liquidity decreases, the profitability also increases; Thirdly, there exists a highly significant negative relationship between average collection period and profitability indicating that a decrease in the number of days a firm receives payment from sales affects the profitability of the firm positively; Fourthly, there is a highly significant positive relationship between average payment period and profitability. This implies that the longer a firm takes to pay its creditors, the more profitable it is.; and Fifthly, there exists a highly significant negative relationship between inventory turnover in days and profitability hinting that firms which maintain sufficiently low inventory levels reduce the cost of storing the inventory which results to higher profitability.
\end{abstract}

Keywords: Working Capital, Profitability, Manufacturing Companies, Dar es Salaam Stock Exchange, Tanzania

\section{Introduction}

Business plays a vital role in the capital formation of a country and people consider it as the life blood of a growing economy. Therefore, it is very important to manage business effectively and efficiently. One of the major issues encountered by fund managers today is not just the procurement of funds but also their meaningful deployment to generate maximum returns. Working Capital Management (WCM) is an important corporate financial decision since it directly affects the profitability of the firm. Working capital management efficiency is vital especially for manufacturing firms, where a major part of assets is composed of current assets especially inventory and trade receivables, Arunkmar and Ramanan (2013)

Working Capital mainly represents the current assets of a firm which is the portion of financial resources of business that change from one type to another during the day-to-day execution of business Deloof (2003). Current assets mainly comprise of cash, prepaid expenses, short-term investments, accounts receivable and inventory. Net working capital can be measured by deducting current liabilities of a firm from its current assets. If the value of current assets is less than that of current liabilities, net working capital would have a negative value showing a deficit working capital. When a business entity takes the decisions regarding its current assets and current liabilities it can be termed as working capital management. The management of working capital can be defined as an accounting approach that emphasize on maintaining proper levels of both current assets and current liabilities. Working capital management provides enough cash to meet the short-term obligations of a firm, Raheman 
and Nasr (2007).

Profitability can be termed as the rate of return on investment. If there will be an unjustifiable over investment in current assets, this would negatively affect the rate of return on investment, Raheman and Nasr (2007). The basic purpose of managing working capital is controlling of current financial resources of a firm in such a way that a balance is created between profitability of the firm and risk associated with that profitability, Lazaridis and Tryfonidis (2006).

Every business requires working capital for its survival. Working capital is a vital part of business investment which is essential for continuous business operations. It is required by a firm to maintain its liquidity, solvency and profitability, Lazaridis and Tryfonidis (2006). Working Capital management explicitly impacts both the profitability and level of desired liquidity of a business. Hence, it may have both negative and positive impact on firm's profitability, which in turn, has negative and positive impact on the shareholders' wealth, Raheman \& Nasr (2007). If a firm invests heavily on working capital i.e. more than its needs, the profits which can be generated by investing these resources in fixed or long term assets diminishes. Moreover the firm have to endure the cost of storing inventory for longer periods as well as the cost of handling excessive inventory, Arnold (2008).

It is therefore a critical issue to know and understand the effects of working capital management and its influence on firm's profitability. Indeed, a lot of research (Mathuva, 2010; Lazaridis and Tryfonidis, 2006; Falope and Ajilore, 2009; Mansoor and Muhammad, 2012; Naimulbari, 2012; Raheman and Nasr, 2007) have been conducted in different countries to show the effects of working capital components on firm's profitability. However, since Tanzania differs from developed and other developing countries in terms of capital markets, economy and infrastructural development, this limited evidence in the context of Tanzania along with the importance of working capital management calls for research on the effects of working capital management on company's profitability. So, the aim of this study is to find out the effects of working capital management on company profitability focusing on listed companies on the Dar es Salaam Stock Exchange (DSE)

\subsection{Motivation to Study}

Working capital management is of a particular importance to the profitability growth. This is because without a proper management of working capital, it's difficult for the firm to run its operations smoothly. That is why Brigham and Houston (2003) conclude that about 60 percent of a typical financial manager's time is devoted to working capital management. Hence, the crucial part of managing working capital is maintaining the required liquidity in day-to-day operation to ensure firm's smooth running and to meet its obligations, Eljelly (2004). Further, working capital management has been a major issue especially in developed countries and as a result, in order to explain the relationship between working capital management and profitability research have been carried out in different parts of the world especially in developed countries.

Researches in the field of working capital include; Teruel and Solan (2005) who suggest that managers can create value by reducing their firm's number of days of accounts receivables and inventories. Similarly reducing the cash conversion cycle also enhances the firm's profitability. Another study is by Deloof (2003) whereby it took into account all firms within geographical areas. However, despite the importance of working capital management, this issue failed to attract the attention of researchers in Tanzania. Studies by (Deloof, 2003; Lazaridis and Tryfonidis, 2006; Falope and Ajilore, 2009; Mansoor and Muhammad, 2012; Naimulbari, 2012; Raheman and Nasr, 2007) used all the firms in a geographical area but this research has a view of only public manufacturing companies listed on the Dar es Salaam Stock Exchange (DSE). This is because most research have been conducted outside Tanzania which in reality there is a big difference on overseas companies in terms of capital invested, size of companies and capital markets compared to the Tanzanian companies. In addition, this research will use only manufacturing sector unlike previous studies like Falope and Ajilore (2009) which included together purely manufacturing firms and service rendering firms (e.g. hospitals, aviation firms, trading companies) without considering the fact that working capital management requirements and practices differ across broad categories of firms. This study attempts to fix this weakness by focusing only on manufacturing firms listed on the DSE.

\section{Literature Review}

\subsection{Relationship between Average Collection Period and Profitability}

Average collection period refers to the average length of time required to convert the firm's receivables into cash following a sale. It is calculated by dividing accounts receivable by the average credit sales per day. This ratio measures the length of time it takes to convert the average sales into cash. This measurement defines the relationship between accounts receivable and cash flow. A longer average collection period requires a higher investment in accounts receivable. A higher investment in accounts receivable means less cash is available to cover cash outflows, such as paying bills.

Mekonnen (2011) shows that there is statistically significant negative relationship between profitability and average collection period. This result suggests that firms can improve their profitability by reducing the number of day's accounts receivable outstanding. Also this can be interpreted as the less the time it takes for customers to pay their bills, the more cash is available to replenish inventory hence the higher the sales realized leading to high profitability of the firm.

The negative relationship between average collection period and profitability suggests that an increase in the number of day's accounts receivable by 1 day is associated with a decline in profitability. Through this, managers can 
improve profitability by reducing the credit granted to their customers, Lazaridis and Tryfonidis (2006).

The study by Deloof (2003), states that managers can increase corporate profitability by reducing the average collection period. The longer the number of day's accounts receivable outstanding, the greater the chance that the firm may lose its profitability. If firms don't manage debtors, they gradually lose control due to reduced cash flow and could experience an increased rate of bad debts. So the longer someone owes firm's money, the greater the chance the firm never get paid. As a result, profit may only be called real profit after the receivables are turned into cash. Therefore, the management of account receivables is inevitable and largely influenced by the credit policy and collection procedure. A credit policy specifies requirements to value the worthiness of customers and a collection procedure provides guidelines to collect unpaid invoices that will reduce delays in outstanding receivables, Brigham and Houston (2003). So, there exists a highly significant negative relationship between the time it takes for firms to collect cash from their customers (receivables collection period) and profitability.

Other authors with the same results of negative relationship between profitability and average collection period include (Mathuva, 2010; Lazaridis and Tryfonidis, 2006; Falope and Ajilore, 2009; Mansoor and Muhammad, 2012; Naimulbari, 2012, Raheman and Nasr, 2007; Dong, 2010; Arunkmar and Ramanan, 2013).

This leads us to propose the following general hypothesis:

$H_{1}$ : There is negative relationship between average collection period and profitability.

\subsection{Relationship between Inventory Turnover in Days and Profitability}

Inventory turnover in days refers to the average time required to convert materials into finished goods. It is calculated as (Inventory/(Cost of goods sold) $\times 365)$. Inventory turnover ratio, which represents the efficiency of inventory management, is expected to be high for firms with greater profitability. A low inventory turnover ratio could indicate either poor sales or an excess amount of inventory, Ruichao (2013). Mansoor and Muhammad (2012) on their study show that managers can improve firms' profitability by shortening inventory collection period.

Dong (2010) focuses on the variables that include profitability, conversion cycle and its related elements and the relationship that exists between them. The research finds that the relationships among these variables are strongly negative. This denote that decrease in the profitability occur due to increase in cash conversion cycle. It is also finds that if the number of days of account receivables and inventories are diminished then the profitability increases.

Although most empirical research suggest a negative relation between inventory turnover in days and profitability (Ruichao, 2013; Lazaridis and Tryfonidis, 2006; Falope and Ajilore, 2009; Mansoor and Muhammad, 2012; Raheman and Nasr, 2007; Dong, 2010), find contradictory findings on the relationship between inventory turnover in days and profitability. Gill, Biger and Mathur (2012) and Mathuva (2010) suggest a positive relationship between inventory turnover in days and profitability. Maintaining sufficiently high inventory levels reduces costs of possible interruptions in the production process and loss of doing business due to scarcity of products (Mathuva 2010), while investing too much in inventories unnecessarily blocks the funds in working capital that could be invested in revenue generating activities. Since inventory determines the level of activities in a company, managing it strategically contributes to profitability (Brigham and Houston, 2003). The key to manage inventory of a business is to know how quickly firm's overall stock is moving, how long each item of stock sits on shelves before being sold. Managing inventory is a juggling act. Excessive stocks can place a heavy burden on the cash resources of a business. Insufficient stocks can result in lost sales, delays for customers etc. The key issue for a business is to identify the fast and slow stock movers with the objectives of establishing optimum stock levels for each category and, thereby, minimize the cash tied up in stocks. The stock sitting on shelves for long periods of time ties up money which may reduce the profitability of firms.

Thus, in light of the above theoretical grounds, the following research hypothesis is developed:

$\mathrm{H}_{2}$ : There is a negative relationship between inventory turnover in days and profitability.

\subsection{Relationship between Average Payment Period and Profitability}

Average payment period can be defined as the average length of time between the purchase of materials and labor and the payment of cash for them. It is calculated as; (Payables $/($ Purchase $) \times 365)$. Account payables plays a critical role in managing working capital because delaying bill payments is one of the tools for management to have access to an inexpensive source of financing. However, the opportunity cost of keeping high account payables may hurt the business if an early payment discount is offered, Ruichao (2013). Payment period tend to be longer for countries in insufficient and smaller capital markets like Tanzania whereby there are only 20 listed companies which includes 13 domestic companies and 7 foreign companies, Porta et al's study as cited in Ruichao (2013).

Working capital management rule states that firms should strive to lag their payments to creditors as much as possible, taking care not to spoil their business relationship. Through this, Mathuva (2010) in the study "the influence of working capital management components on corporate profitability: a survey on Kenyan listed firms" shows that average payment period has a positive relationship with profitability. The positive relationship suggests that an increase in the number of day's accounts payable by 1 day is associated with an increase in profitability.

Delaying payment of accounts payable to suppliers allows firms to access the quality of branch products and could be inexpensive and flexible source of financing. On the other hand, delaying of such payables can be expensive if a firm is 
offered a discount for the early payment. So, there exists a highly significant positive relationship between the time it takes the firm to pay its creditors (average payment period) and profitability, Naimulbari (2012).

Although studies by (Ruichao, 2013; Muthuva, 2010; Naimulbari, 2012, Gill, Biger and Mathur, 2012) show positive relationship between accounts payment period and profitability other more research by (Ray, 2012; Mekonnen, 2011; Deloof, 2003; Reheman \& Nasr, 2007; Vural, Sökmen and Çetenak, 2012; Saghir, Hashmi and Hussain, 2011; Reheman et al, 2010) suggest a negative relationship between average payment period and the firm profitability. GarciaTeruel and Martinez-Solano (2007) failed to provide the relationship that exists between average payment period and profitability.

In view of the earlier explanations we hypothesize as follows:

$H_{3}$ : There is a positive relationship between average payment period and profitability.

\subsection{Relationship between Cash Conversion Cycle and Profitability}

Cash conversion cycle equals the length of time between the firm's actual cash expenditures to pay for productive resources (materials and labor) and its own cash receipts from the sale of products (that is, the length of time between paying for labor and materials and collecting on receivables). The cash conversion cycle thus equals the average length of time a shilling is tied up in current assets. It is calculated as; (Average Collection Period + Inventory turnover in days Average Payment Period) Brigham and Houston (2003). Cash conversion cycle can be shortened in three ways: One, by reducing inventory conversion period by processing and selling goods more quickly. Two by reducing receivables period by speeding up collections from sales and three by lengthening payables or deferral period through slowing down firm's own payments.

Naimulbari (2012) in the study "The impact of working capital management on profitability" of pharmaceuticals sector in Bangladesh" shows that there is a negative relationship between cash conversion cycle and profitability. As the cash conversion cycle has the negative relationship with the profitability, this cycle should be short as much as possible without hurting the operations. This would improve profits, because the longer the cash conversion cycle, the greater the need for external financing, and that financing has a cost.

The study by Dong (2010), reports that the firms' profitability and liquidity are affected by working capital management. From the research it is found that the relationship between CCC and profitability is strongly negative. This denotes that decrease in the profitability occurs due to increase in cash conversion cycle.

Despite many authors postulating a negative relationship between cash conversion cycle and profitability, (Azam and Haider, 2011; Mansoor and Muhammad, 2012; Mekonnen, 2011; Dr. Ray, 2012; Vural, Sökmen and Çetenak, 2012; Saghir, Hashmi and Hussain, 2011; Niresh, 2012; Reheman et al., 2010; Naimulbari, 2012), there are studies which indicate a positive relationship between cash conversion cycle and profitability (Gill, Biger and Mathur, 2012; Lyroudi \& Lazaridis, 2000).

This leads us to the following hypothesis:

$H_{4}$ : There is a negative relationship between cash conversion cycle and profitability.

\subsection{Relationship between Liquidity and Profitability}

Liquidity refers the amount of cash a company can put its hands on quickly to settle its debts (and possibly to meet other unforeseen demands for cash payments too). For the purpose of this research, current ratio (CAR) is used as a measure of liquidity and calculated by dividing current assets by current liabilities. Finance managers have to take various types of financial decisions like investment decision, finance decision, liquidity decision and dividend decision, in different times. In every area of financial management, the finance managers are always faced with the dilemma of liquidity and profitability, hence have to strike a balance between the two, Eljelly (2004).

Most of the time, liquidity goals of a firm is to have adequate cash to pay for its bills, to make large unexpected purchases and finally, firm has an adequate cash reserve to meet emergencies in all time. Whereas, profitability goal on the other hand requires that, funds of a firm are used so as to yield higher returns. Therefore, when one increases, the other decreases, Brigham and Houston (2003).

Apparently, liquidity and profitability goals conflict in most of the decisions the finance managers make. Higher inventories are kept in anticipation of increase in prices of raw materials; hence, profitability goal is approached but the liquidity position of a firm is endangered. In reality, none of the managers choose any of these two extremes instead they want to have a balance between profitability and liquidity which fulfils their need of liquidity and gives required level of profitability, Arnold (2008).

Mekonnen (2011) finds that there is a significant negative relationship between liquidity and profitability. Similarly Eljelly (2004) empirically examines the relationship between profitability and liquidity, as measured by current ratio and cash gap (cash conversion cycle) on a sample of 929 joint stock companies in Saudi Arabia, finds a significant negative relationship between the firm's profitability and its liquidity level.

Raheman and Nasr (2007) on their study about the effect of different variables of working capital management including average collection period, inventory turnover in days, average payment period, cash conversion cycle, and current ratio on the net operating profitability of Pakistani firms, selected a sample of 94 Pakistani firms listed on Karachi Stock Exchange for a period of six years from 1999 2004 and found a strong negative relationship between liquidity (as measured by current ratio) and profitability of the firm.

In contrast other studies (Naimulbari, 2012; Azam and Haider, 2011) show a positive correlation between gross 
operating profitability and current ratio. This shows that as the firm's current ratio increases, the gross operating profitability also increases. In view of this explanation, therefore hypothesize:

$H_{5}$ : There is a negative relationship between liquidity and profitability.

\section{Methodology}

\subsection{Research Design}

This is a multiple case study research where 30 observations from the three manufacturing companies listed on DSE qualified to have ten years financial information needed for the study. The quantitative research approach is employed to arrive at the conclusions where correlation analysis is used to identify the nature of the relationship of the variables and also regression analysis specifically Ordinary Least Squares (OLS) is used to find out the relationship and extent of the effect of working capital management variables on profitability.

\subsection{Data Collection}

Annual financial statements (statement of comprehensive income and statement of financial position) are used to collect data of the firms incorporated in this study; these reports are from a reliable source which is the Dar es Salaam Stock Exchange (DSE) reports for the period of ten years from 2002 to 2012.

The target population of this research is 6 manufacturing companies listed on the DSE in Tanzania according to Dar es Salaam Stock Exchange website as at 25/11/2014. There are 20 listed companies but other companies are not in manufacturing sector. This study takes a sample of 3 manufacturing companies which qualify for giving us information needed for research for the period of ten years making $(50 \%)$ of the population for the study.

\subsection{Variables and Measurement}

In this study, the choice of explanatory variables is based on alternative theories related to working capital management and profitability and additional variables that were used in previous studies. The variables used in this study are based on the line as applied in previous research regarding the relationship between working capital management and profitability. These variables are categorized as follows:

Dependent Variable: Gross Operating profitability (GOP); GOP is a measure of Profitability of the firm. It is defined as Sales minus Cost of Goods Sold and divided by total assets minus financial assets.

Independent Variables: Average Collection Period (ACP); ACP is used as a proxy for the collection policy. It is calculated as; (Receivables/(Sales) $\times 365)$, Inventory turnover in days (ITD); Inventory conversion period is used as proxy for the inventory policy. It is calculated as; (Inventory $/($ Cost of goods sold) $\times 365)$, Average Payment Period (APP); APP has been used as proxy for the payment policy. It is calculated as; (Payables/ $($ Purchase $\times 365)$ and Cash Conversion Cycle $(\mathrm{CCC})$; Cash Conversion Cycle is used as a comprehensive measure for working capital management. It is calculated as; (Average Collection Period + Inventory turnover in days - Average Payment Period)

\subsection{Model Specification}

Ordinary Least Squares (OLS) regression model is used: $\mathrm{GOP}=\beta_{0}+\beta_{1}\left(\mathrm{ACP}_{\mathrm{it}}\right)+\beta_{2}\left(\mathrm{APP}_{\mathrm{it}}\right)+\beta_{3}\left(\mathrm{ITD}_{\mathrm{it}}\right)+\beta_{4}\left(\mathrm{CCC}_{\mathrm{it}}\right)+\beta_{5}\left(\mathrm{CAR}_{\mathrm{it}}\right)+\varepsilon$.

where $: \beta_{0}=$ Intercept of the equation and $\beta_{1}, \beta_{2}, \ldots \beta_{8}=$ Coefficients and $\varepsilon=$ Error term.

Pearson correlation is used to measure the degree of association between different variables under consideration and regression analysis is used to estimate the extent and direction of relationships between profitability and working capital variables.

\section{Findings}

\subsection{Descriptive Statistics}

Table 4.1 presents a summary of descriptive statistics of the dependent and independent variables for three manufacturing companies listed on the DSE for a period of 10 years from 2002 to 2012 making a total of 30 study observations.

Table 4.1. Descriptive Statistics.

\begin{tabular}{lllllllllll}
\hline & ACP & ITD & APP & CCC & CAR & FIS & LEV & SAG & GOP \\
\hline N & 30 & 30 & 30 & 30 & 30 & 30 & 30 & 30 & 30 \\
Mean & 20.87 & 112.57 & 73.60 & 59.93 & 2.15 & 15.85 & 0.34 & 0.19 & 0.60 \\
Std. Dev & 7.44 & 16.78 & 29.06 & 28.33 & 1.08 & 3.22 & 0.11 & 0.20 & 0.14 \\
Min & 10.72 & 79.29 & 50 & -23.98 & 0.57 & 11.45 & 0.21 & -0.33 & 0.35 \\
Max & 39.64 & 150.52 & 184.11 & 100.97 & 3.91 & 19.98 & 0.56 & 0.82 & 0.92 \\
\hline
\end{tabular}


Table 4.1 shows that the average value of gross operating profitability is $60 \%$ of total sales, and standard deviation is $14 \%$. This means that the value of profitability can deviate from the mean to both sides by $14 \%$. The maximum and minimum values of gross operating profitability are $92 \%$ and $35 \%$ respectively. Information from descriptive statistics also indicates that the mean of cash conversion cycle that used as a comprehensive measurement of managing working capital is 60 days and standard deviation is 28 days. The maximum and minimum values of cash conversion cycle are 101 days and -24 days respectively.

Firms receive payment against sales after an average of 21 days and standard deviation is 7 days. Minimum time taken by a company to collect cash from receivables is 11 days while the maximum time for this purpose is 40 days. It takes an average 113 days to sell inventory with standard deviation of 17 days. The maximum time taken by a company to sell inventory is 151 days, which is not a very large time period to convert inventory into sales for manufacturing firms. Firms wait an average 74 days to pay their purchases with standard deviation of 29 days. The minimum time taken by a company to pay its purchases is $\mathbf{5 0}$ days and maximum time taken for this purpose is 184 days.

The size of the firm and its relationship with profitability as measured by natural logarithm of sales is used as a control variable. The mean value of $\log$ of sales is 15.85 while the standard deviation is 3.22 . The maximum value of $\log$ of sales for a company in a year is 19.98 and the minimum is 11.45. In the same way to check the liquidity of the companies, a traditional measure of liquidity is used. The average current ratio for manufacturing firms listed on DSE is 2.15 with a standard deviation of 1.08 . The highest current ratio for a company in a particular year is 3.91 times and in the same way the minimum ratio for a company in a year is 0.57 . The average leverage is 0.34 with a standard deviation of 0.11 . The maximum and minimum of leverage are 0.56 and 0.21 respectively.

\subsection{Correlation Analysis}

Table 4.2 presents the Pearson correlation for the variables that are used in the regression model. Pearson's correlation analysis is used to find the relationship between working capital management and gross operating profit.

Table 4.2. Correlation analysis between working capital variables and profitability.

\begin{tabular}{|c|c|c|c|c|c|c|c|c|}
\hline & ACP & ITD & APP & $\mathrm{CCC}$ & CAR & FIS & LEV & SAG \\
\hline $\mathrm{ACP}$ & 1 & & & & & & & \\
\hline ITD & 0.067 & 1 & & & & & & \\
\hline APP & 0.373 & 0.239 & 1 & & & & & \\
\hline $\mathrm{CCC}$ & -0.083 & 0.360 & -0.787 & 1 & & & & \\
\hline CAR & 0.251 & 0.305 & 0.334 & -0.077 & 1 & & & \\
\hline FIS & -0.155 & 0.122 & -0.132 & 0.170 & -0.305 & 1 & & \\
\hline LEV & 0.031 & -0.108 & 0.341 & -0.411 & 0.240 & -0.623 & 1 & \\
\hline SAG & 0.122 & -0.096 & 0.021 & -0.024 & 0.122 & -0.004 & 0.105 & 1 \\
\hline
\end{tabular}

The table shows how variables relate to one another in the process of making company profitability.

ACP is related positively to ITD, APP and CAR meaning that as ACP increases ITD, APP and CAR also increase. There is a negative relationship between ACP and CCC and FIS which show that as ACP goes up CCC increases.

ITD has a positive relationship with APP, CCC and CAR meaning that as ITD increases APP, CCC and CAR also increase.

APP has a positive relationship with CAR showing that as APP increases CAR also increases while it relates negatively with CCC.

Finally, there exists a negative relationship between CCC and CAR indicating that CAR is lower when CCC is higher.

\subsection{Regression Analysis}

The results of the regression analysis are shown on Table 4.3. This shows the extent on how working capital variables affect companies' profitability.
Table 4.3. OLS regression of dependent and independent variables.

\begin{tabular}{lllll}
\hline Variable & Coefficients & Std Error & t- Stat & P-value \\
\hline Constant & 0.714 & 0.272 & 2.623 & 0.016 \\
ACP & -0.040 & 0.013 & -3.108 & 0.005 \\
ITD & -0.039 & 0.013 & -3.043 & 0.006 \\
APP & 0.042 & 0.013 & 3.177 & 0.004 \\
CCC & 0.041 & 0.013 & 3.134 & 0.005 \\
CAR & -0.023 & 0.025 & -0.900 & 0.378 \\
FIS & -0.017 & 0.009 & -1.862 & 0.077 \\
LEV & 0.011 & 0.293 & 0.037 & 0.971 \\
SAG & -0.285 & 0.120 & -2.374 & 0.027 \\
R & 0.470 & & & \\
Adjusted $R^{2}$ & 0.260 & & & \\
F-value & 2.300 & & & \\
\hline
\end{tabular}

The adjusted $R^{2}$ of the model is $26 \%$ and value for the $\mathrm{R}^{2}$ in the model is 0.47 which endorses that $47 \%$ of the variation in the dependent variable is explained by the model. The 53\% variation in the dependent variable remains unexplained by 
the independent variables of the study.

The results of regression indicate that the coefficient of ACP is negative with -0.040 and p-value of 0.016 . This implies that the increase or decrease in ACP will significantly affect profitability of firm. APP has a positive coefficient of 0.042 with p-value (0.004) implying that the increase or decrease in the average payment period, significantly affects profitability of the firm. The positive relationship between average payment period and profitability indicates that the more profitable firms wait longer to pay their bills.

The cash conversion cycle is used to measure efficiency of working capital management. Regression results indicate that there is a positive (0.041) relationship between cash conversion cycle and operating profitability which implies that the increase or decrease in the cash conversion cycle significantly affects profitability of the firm. Also inventory turnover in days shows a negative (-0.039) relationship with profitability which indicates that if the inventory turnover in days increases the profitability decreases.

Leverage ratio used as a proxy for leverage has a significant positive relationship with the dependent variable, which means that, when leverage of the firm increases, profitability also increases. The size of the firm has a negative impact on profitability implying that with the increase in size, profitability declines, sales growth also shows a negative relationship with profitability which indicates that when the sales growth increases, the profitability decreases, and the current ratio has a positive impact on profitability.

\section{Discussion}

\subsection{Relationship between Average Collection Period and Profitability}

Regarding the average days of accounts receivables, previous studies (Mathuva, 2010; Lazaridis and Tryfonidis, 2006; Falope and Ajilore, 2009; Mansoor and Dr. Muhammad, 2012; Naimulbari, 2012; Raheman and Nasr, 2007; Dong, 2010) reported a negative relationship between ACP and the profitability of the firm. Similarly, the researcher finds a negative relationship between ACP and profitability. This suggests that an increase in number of days a firm receives payment from sales affects the profitability of that firm negatively.The negative relationship between average collection period and profitability also suggests that a decrease in the number of day's accounts receivable by 1 day is associated with increase in profitability. The findings can also be interpreted in that increase in amounts of account receivable has opportunity costs and bad debt hence profitability of the firm is affected negatively in the long-run. These findings are in line with the working capital management rule that firms should strive to collect their debts from debtors as quickly as possible, taking care not to spoil their business relationship. Therefore, whenever collection period increases bad debt increase and hence profitability falls down and whenever collection period decreases bad debts decrease and hence profitability increases.

\subsection{Relationship between Inventory Turnover in Days and Profitability}

The relationship between ITD and GOP is negative thus consistent with (Ruichao, 2013; Lazaridis and Tryfonidis, 2006; Falope and Ajilore, 2009; Mansoor and Muhammad, 2012; Raheman and Nasr, 2007; Dong, 2010) who found a strong negative relationship between ITD and profitability. However, the findings contradict (Gill, Biger and Mathur, 2012; Naimulbari, 2012; Mathuva 2010) who show positive relationship between ITD and profitability. This implies that when the average time required in converting materials into finished goods and then to sell those goods decreases, it leads to an increase in profitability. Manufacturing companies have large inventories as composed of raw materials and finished goods and therefore there is a need to sell goods produced quickly so as to make profits. In general, this finding can be interpreted that if the inventory takes more time to sell, it will adversely affect profitability (Profitability decreases).

\subsection{Relationship between Average Payment Period and Profitability}

There exists a positive relationship between average payment period and profitability. This is consistent with (Muthuva, 2010; Naimulbari, 2012 and Gill, Biger and Mathur, 2012) suggesting that an increase in the number of day's accounts payable by 1 day is associated with an increase in profitability. This result makes economic sense in that the more a firm delays its payments to its creditors, the higher the level of working capital it reserves and uses in order to increase profitability. The results are contrary to (Ray, 2012; Mekonnen, 2011; Deloof, 2003; Reheman \& Nasr, 2007; Vural, Sökmen and Çetenak, 2012; Saghir, Hashmi and Hussain, 2011 and Reheman et al, 2010) who show that less profitable firms wait longer to pay their bills. The results imply that firms withhold their payment to suppliers so as to take advantage of the cash available for their working capital needs. These findings are in line with the working capital management rule that firms should strive to lag their payments to creditors as much as possible, taking care not to spoil their business relationships.

\subsection{Relationship between Cash Conversion Cycle and Profitability}

The findings contradict (Azam and Haider, 2011; Mansoor and Muhammad, 2012; Mekonnen, 2011; Ray, 2012; Vural, Sökmen and Çetenak, 2012; Saghir, Hashmi and Hussain, 2011; Niresh, 2012; Reheman et al, 2010; Naimulbari, 2012) who found a negative relationship between cash conversion cycle and company profitability but consistent with (Gill, Biger and Mathur, 2012; Lyroudi \& Lazaridis, 2000) who show a positive relationship between cash conversion cycle and company profitability. The findings can be interpreted that when the cash conversion cycle increases the 
profitability also increases.

The positive relationship between profits and cash conversion cycle could be explained by the nature of firms and higher profitability due to market dominance. Manufacturing firms maintain more inventories due to high production, to carter for seasonality effect and avoid the costs of stock outs and price fluctuations. The positive relationship between the firm's cash conversion cycle and profitability can also be explained by the fact that maximizing the investment in current assets can help in boosting profits. This shows that little liquid cash is maintained in the business for operations.

\subsection{Relationship between Liquidity and Profitability}

The result of this relationship is in line with (Mekonnen, 2011; Eljelly, 2004; Raheman and Nasr, 2007) studies which show a negative relationship between liquidity and profitability. This suggests that as the firm's current ratio decreases, the gross operating profitability increases. It indicates that the two objectives of liquidity and profitability have inverse relationship.

\section{Conclusion}

The management of working capital is one of the most important financial decisions of a firm. Sufficient level of working capital should be present for smooth running of a company regardless of the nature of business. The management of a firm can create value for their shareholders by reducing the number of day's accounts receivable; this is because as the ACP decreases, the profitability of the manufacturing firms increases. It is noted that as ACP increases, the level of bad debt also increases which in the long-run results to reduction in profitability. The management can also create value for their shareholders by reducing their inventories to a reasonable level since the results indicate that profitability increases as the ITD decreases. When the ITD increases, storage costs also increase in order to keep the available inventory. Firms can also take long time to pay their creditors in as far as they do not strain their business relationships with these creditors as indicated by profitability increases with an increase in APP. In addition, firms can also reduce the liquidity level in order to gain the overall firms' performance; this is indicated by a negative relationship between profitability and liquidity.

Firms are capable of gaining sustainable competitive advantage by means of effective and efficient utilization of the resources of the organization through increasing of the cash conversion cycle. In so doing, the profitability of the firms is expected to increase. Management of working capital means "management of current assets and current liabilities, and financing these current assets". If these firms properly manage their cash, accounts receivables and inventories, this ultimately increases their profitability.

Future research should investigate generalization of the findings beyond the companies listed on Dar es Salaam Stock Exchange. Also, the scope of further research should be extended to more working capital variables and profitability measures' including cash, marketable securities and ROA, ROE respectively and extended in terms of number of years.

\section{References}

[1] Arnold, G. (2008). Corporate financial management 4th edition. Pearson education limited; New York

[2] Arunkumar O.N \& Ramanan T.R (2013) Working Capital Management and profitability: A Sensitivity Analysis. International Journal of Research and Development: A Management review. Vol 2, pp 52 - 58

[3] Brigham, F. and Houston, F. (2003), 'Fundamentals of financial management', 10th ed. McGraw-Hill Inc: New York

[4] Deloof M (2003), 'Does working capital management affect profitability of Belgian firms', Journal of Business Finance and Accounting, Vol 30, No. $3 \& 4$, pp. 573-588.

[5] Dong H. P. (2010), "The Relationship between Working Capital Management and Profitability". International Research Journal of Finance and Economic. Issue-49.

[6] Dr Ray, S. (2012) “Evaluating the Impact of Working Capital Management Components on Corporate Profitability: Evidence from Indian Manufacturing Firms" International Journal of Economic Practices and Theories, Vol. 2, No. 3, pp. $2247-7225$

[7] Dr. Azam, M and Haider, S. I. (2011), "Impact of Working Capital Management on Firms' Performance: Evidence from Non-Financial Institutions of KSE-30 index", Interdisciplinary Journal of Contemporary Research in Business, Vol 3, No 5, pp. $481-492$.

[8] Eljelly A. (2004), Liquidity-profitability trade-off: an empirical investigation in an emerging market. International Journal of Commerce and Management, Vol 14, No. 2, pp. 48-61

[9] Falope, O. I, Ajilore O. T (2009), "Working capital management and corporate profitability: evidence from panel data analysis of selected quoted companies in Nigeria", Research Journal of Business Management, vol.3: pp. 73-84.

[10] Gill, A., Biger, N., Mathur, N. (2010). "The relationship between working capital management and profitability: Evidence from the United States", Business and Economics Journal, 10, 1-9.

[11] Kazi Naimulbari MD. (2012) “The Impact of Working Capital Management on Profitability" of pharmaceuticals sector in Bangladesh. Unpublished undergraduate, research work: independent university, Bangladesh

[12] Lazaridis, I. and Tryfonidis, D. (2006), 'Relationship between working capital management and profitability of listed companies in the Athens stock exchange', Journal of Financial Management and Analysis, Vol 19(1)

[13] Mansoori, E. and Dr. Muhammad (2012), "The Effect of Working Capital Management on Firm's Profitability: Evidence from Singapore” Interdisciplinary Journal of Contemporary Research in Business, Vol 4, No 5, pp 472 - 486

[14] Mathuva, D. M. (2010) "The Influence of Working Capital Management Components on Corporate Profitability: A Survey on Kenyan Listed Firms", Research Journal of Business Management, 4(1): 1-11. 
[15] Mekonnen, Mulualem(2011) "The Impact Of Working Capital Management On Firms' Profitability" Unpublished Master Thesis, Addis Ababa University: Ethiopia

[16] Raheman et al (2010) "Working Capital Management and Corporate Performance of Manufacturing Sector in Pakistan", International Research Journal of Finance and Economics, 47: 151-163.

[17] Raheman, A. and Nasr M., (2007), 'Working capital management and profitability - case of Pakistani firms', International Review of Business Research Papers

[18] Ruichao, Lu (2013). Impact of Working Capital Management on Profitability: The Case of Canadian Firms: Unpublished Master Thesis, Saint Mary's University: Canada.

[19] Saghir, A., Hashmi, F, M., and Hussain, M, N (2011), "Working Capital Management and Profitability: Evidence from Pakistan Firms", Interdisciplinary Journal of
Contemporary Research in Business, Vol 3, No 8, pp. 1092 1105

[20] Teruel P and Solan P. (2005). "Effects of Working Capital Management on SME Profitability", Working Paper series: Spain

[21] Teruel PJG and Solano PM. (2007). "Effects of Working Capital Management on SME Profitability", International Journal of Managerial Finance, Vol. 3, No. 2, pp. 164-177, 2007.

[22] Velnampy, T. and Niresh, J.A. (2012). "The Relationship between Capital Structure and Profitability", Global Journal of Management and Business Research, Vol. 12 (13).

[23] Vural, G. Sökmen, A.G and Çetenak, E. H (2012). "Affects of Working Capital Management on Firm's Performance: Evidence from Turkey", International Journal of Economics and Financial Issues Vol. 2, No. 4, 2012, pp.488-495 